\title{
Engels e a dialética hegeliana: sistema, método, ciência e efetividade
}

\author{
Engels and the Hegelian dialectics: System, Method, Science, and \\ Effectiveness
}

\author{
Vitor Bartoletti Sartori \\ vitorbsartori@gmail.com \\ (Universidade Federal de Minas Gerais, Minas Gerais, Brasil)
}

\begin{abstract}
Resumo: Trataremos da posição de Engels quanto à ciência e à dialética, procurando demonstrar que há certa tensão em seu pensamento, colocada na oposição entre o seu modo de pesquisa e seu modo de exposição. Ao passar sobre sua teorização sobre as ciências positivas, também constataremos tensões, que se explicitam, de um lado, na crítica ao sistema hegeliano, noutro no modo como o autor toma expressões e categorias do próprio Hegel para sua compreensão sobre a dialética, em oposição à metafísica.
\end{abstract}

Palavras-chave: Engels; sistema; método; dialética; Hegel.

\begin{abstract}
Here, we will deal with Engels' position regarding science and dialectics. We will try to show that there is a tension between his mode of research and his mode of exposition. In his theorization on positive sciences, we will also note certain tensions, which are made explicit on the one hand, in the critic of the Hegelian system; we will also analyze the way the author, sometimes, relies on Hegelian categories and expressions on the critic of metaphysics.
\end{abstract}

Keywords: Engels; system; method; dialectics; science; Hegel.

\section{Introdução}

Friedrich Engels nem sempre é estudado com o mesmo afinco que seu grande amigo Karl Marx. Isto ocorre, primeiramente, devido aos méritos do próprio autor de $O$ capital, que, como reconheceu o próprio Engels, teve uma envergadura teórica maior. Isto se deu a tal ponto que ocorreu uma espécie de divisão do trabalho entre os dois autores, como disse Engels: "em consequência da divisão de trabalho existente entre Marx e eu, coube-me defender nossos pontos de vista na imprensa periódica, particularmente na luta contra opiniões adversárias"; ou seja, a posição marxiana é vista como aquela de mais fôlego, ao passo que, de imediato, a tarefa engelsiana seria mais modesta. $\mathrm{O}$ autor teria aceitado tal papel "para que Marx tivesse tempo 
necessário para elaborar sua grande obra" (Engels, 1988, p. 8). Ou seja, de certo modo, Engels é o primeiro a reconhecer a importância maior do pensamento de seu amigo se comparado com o seu. No entanto, a questão precisa ser vista com mais cuidado: se, quando Marx ainda vivia, não obstante os autores tenham produzido textos importantes em coautoria (basta pensar no Manifesto, bem como na Sagrada Família), Engels pode ter tido um papel secundário, isto não necessariamente se confirma sob todos os aspectos ao analisarmos a dimensão da obra engelsiana post festum, quando avaliamos a sua influência na formação do marxismo.

O Anti-Dühring, mais precisamente uma parte dele publicada posteriormente como Do socialismo utópico ao socialismo científico, teve papel central na formação de toda uma geração de marxistas. E se trata da geração que teve contato, de um lado, com a expansão do marxismo pela II Internacional, e, doutro, com um dos grandes acontecimentos do século XX, a Revolução Russa. Ou seja, olhando por este aspecto, a influência de Engels foi enorme. Se ela condiz com aquilo que o próprio autor disse, é algo distinto.

E, assim, é preciso destacar que tais circunstâncias, assim como aquelas diametralmente opostas do final do século XX e do começo do século XXI, em que as críticas à Revolução Russa, bem como ao marxismo que se desenvolveu sob seus auspícios, fizeram com que a especificidade do pensamento engelsiano nem sempre fosse apreendida de modo rigoroso. Tem-se certo descuido: por vezes, as concepções de Engels são simplesmente subsumidas às de Marx; ou, o que não foi incomum, as de Marx às de Engels (cf. Sartori, 2015). Doutro lado, há autores que creditam a Engels as mazelas do marxismo, procurando isentar Marx (cf. Musse, 2005). No começo do século XX, salvo raras exceções, como Lukács (2002) - que, na época, tendeu a ser até mesmo excessivamente duro com o autor do Anti-Dühring sob alguns aspectos (cf. Lukács, 2010, 2011) -, houve certa tendência a tratar os dois autores como um bloco monolítico e indiferenciado. Já do final do século XX para a frente tevese certa condenação de Engels como algo necessário à defesa do marxismo e das posições do próprio Marx. Para salvar o marxismo, alguns jogaram Engels na fogueira. 0 contexto, e as disputas que se colocam em torno do legado marxiano na época, de certa maneira, explicam tais posturas, que redundam em certa negligência. Porém, hoje, não a justificam de modo algum, sendo preciso apreender a especificidade do pensamento propriamente engelsiano (cf. Sartori, 2020). Aqui pretendemos contribuir neste sentido.

Ambas as posições mencionadas - com todos os meandros existentes nos distintos pontos de vista - certamente são, de um modo ou doutro, redutoras. Isto ocorre não só porque Engels procura uma nova lida com questões que Marx não chegou a tratar de modo sistemático (cf. Musse, 1999), mas também porque a correlação entre 
modo de exposição e modo de pesquisa ${ }^{1}$ em Engels é significativamente diferenciada daquela do autor de 0 capital (cf. Sartori, 2020). Aqui, a partir daquilo que José Chasin chamou de análise imanente ${ }^{2}$, pretendemos explicitar um aspecto específico do pensamento de Engels, sua relação com a dialética e, em especial, com Hegel. Para tanto, passaremos pela especificidade da exposição engelsiana e, a partir disto, analisaremos sua posição.

\section{Dialética, sistema e ciências positivas em Engels}

No final de sua vida, Engels toma como essencial a tarefa de divulgação. 0 autor diz que "devemos a Marx essas duas grandes descobertas: a concepção materialista da história e a revelação do mistério da produção capitalista mediante o maisvalor." No que continua ao dizer que, com elas, tem-se algo essencial à ciência e ao desenvolvimento da posição socialista: "elas fizeram do socialismo uma ciência que agora deve, em primeiro lugar, continuar a ser elaborada em todos os seus pormenores e em todas as suas conexões” (Engels, 2015, p. 56). Ou seja, a divulgação engelsiana tem uma dupla face: de um lado, é preciso explicitar, inclusive de modo sistemático, as duas grandes descobertas de Marx; doutro, é preciso desenvolver, para além de Marx, as consequências de suas descobertas. Neste sentido, seria preciso reafirmar - na imprensa periódica, inclusive - tais pontos de partida; diante do crescimento da influência de autores ecléticos e sem rigor como Dühring e Menger, seria preciso dar um passo cuidadoso e, assim, repisar os princípios básicos da posição que foi desenvolvida em conjunto com Marx.

Um lado essencial da atuação engelsiana se dá no confronto, em que se reafirmam pontos de partida que, em uma concepção científica, deveriam ser basilares.

Tal tarefa tomaria lugar contra os autores mencionados. Para isto, inclusive, seria necessário partir da exposição destes autores: o Anti-Dühring é dividido por

\footnotetext{
1 A correlação entre modo de pesquisa e de exposição é destacada por Marx em $O$ capital. Veja-se a passagem na íntegra: "é, sem dúvida, necessário distinguir o método de exposição formalmente do método de pesquisa. A pesquisa tem de captar detalhadamente a matéria, analisar as suas várias formas de evolução e rastrear sua conexão íntima. Só depois de concluído esse trabalho é que se pode expor adequadamente o movimento real. Caso se consiga isso, e espelhada idealmente agora a vida da matéria, talvez possa parecer que se esteja tratando de uma construção a priori" (Marx, 1996 a, p. 140). Para a análise da relevância dela na crítica marxiana a Hegel, bem como às posições inspiradas no autor, cf. Sartori, 2014.

2 Como diz Chasin: "tal análise, no melhor da tradição reflexiva, encara o texto - a formação ideal em sua consistência autossignificativa, aí compreendida toda a grade de vetores que o conformam, tanto positivos como negativos: o conjunto de suas afirmações, conexões e suficiências, como as eventuais lacunas e incongruências que o perfaçam. Configuração esta que em si é autônoma em relação aos modos pelos quais é encarada, de frente ou por vieses, iluminada ou obscurecida no movimento de produção do para-nós que é elaborado pelo investigador, já que, no extremo e por absurdo, mesmo se todo o observador fosse incapaz de entender o sentido das coisas e dos textos, os nexos ou significados destes não deixariam, por isso, de existir" (Chasin, 2009, p. 26).
} 
temas, tal qual ocorre na obra do antagonista de Engels. O Socialismo jurídico, embora passe pela correlação entre as diversas esferas do ser social, traz uma ênfase no Direito, mais precisamente, na necessidade da crítica ao Direito e ao terreno jurídico. Assim, a parte mais primária da tarefa engelsiana envolve reafirmar aquilo que deveria ser um ponto de partida de qualquer concepção sóbria sobre a história e sobre a atividade humana, e que se encontra desenvolvido de modo mais elaborado no que nosso autor chama de concepção materialista da história. As descobertas de Marx precisaram se impor diante da pseudocientificidade de autores que, se não fosse pelo próprio Engels, hoje seriam ilustres desconhecidos. A ciência que é mencionada teria isso como pressuposto. Para afirmá-la, porém, nosso autor precisa criticar autores cuja seriedade é de pequena monta se colocada em termos científicos. Engels, assim, não consegue avançar em suas tarefas facilmente: fica preso à tarefa de criticar autores menores e de reafirmar as bases de sua concepção. Tudo aquilo que, com Marx, havia construído, precisaria ser repisado, desde as bases mais fundamentais de um modo materialista de lidar com a ciência.

A afirmação desses pressupostos, assim, não raro, coloca-se de modo polêmico, e a partir da exposição dos autores criticados. Desta maneira, a exposição engelsiana precisa de um momento de popularização das descobertas de Marx diante dos autores com os quais entra em embate. Sua exposição, tal qual a daqueles que critica, torna-se mais sistemática. Isto seria necessário, de um lado, para mostrar como o pensamento que é criticado não se sustenta; doutro, para reafirmar as bases sem as quais uma concepção científica seria impossível. Quer se queira, quer não, a exposição engelsiana ganha uma tonalidade sistemática e, com isto, bem como com certa valorização das ciências positivas, nosso autor passa a ter uma relação mais amistosa com a formação de um sistema materialista de pensamento, que ultrapassaria o idealismo da filosofia clássica alemã e o caráter materialista mecanicista do pensamento iluminista (cf. Musse, 1999).

Engels traz uma relação com a ciência em que ao diletantismo de um Dühring é contraposto, de um lado, uma concepção científica cujas bases são dadas por Marx. Doutro lado, porém, nosso autor procura destacar as ciências de sua época como algo a ser levado a sério de modo cuidadoso, e não como faz o seu antagonista. $E$, deste modo, há certa dubiedade na relação engelsiana com as ciências positivas de sua época: ao mesmo tempo em que ele não deixa de mostrar suas limitações, inserindo-as no aprisionamento da divisão do trabalho burguesa, ele traz elogios tanto a autores das ciências naturais quanto a autores das ciências históricas (cf. Engels, $1979 \mathrm{~b}) .^{3}$

3 Diz nosso autor na Dialética da natureza sobre a concepção renascentista: "foi essa a maior revolução progressista que a humanidade havia vivido até então, uma época que precisava de gigantes e, de fato, engendrou-os: gigantes em poder de pensamento, paixão, caráter, multilateralidade e sabedoria. Os homens que estabeleceram o moderno domínio da burguesia eram alguma coisa em 
O desenvolvimento de uma concepção materialista da história de maneira mais sistemática, porém, não se deve somente à lida de Engels com seus expositores grandes (Hegel, os iluministas) e pequenos (aqueles autores como Dühring e Menger que começam a influenciar o movimento socialista). Esta tarefa é também parte do desenvolvimento da ciência, como disse nosso autor, "elaborada em todos os seus pormenores e em todas as suas conexões" (Engels, 2015, p. 56). Veja-se o que diz nosso autor sobre as ciências positivas e sobre o pensamento dialético, por exemplo. Em oposição a Hegel:

Abandona-se a "verdade absoluta", inalcançável por esta via e por cada um individualmente, e, em troca, perseguimos as verdades relativas alcançáveis pela via das ciências positivas e do compêndio [Zusammenfassung] dos seus resultados por intermédio do pensar dialético. Com Hegel, remata-se, em geral, a filosofia; por um lado, porque ele reuniu todo o desenvolvimento dela no seu sistema, da maneira mais grandiosa; por outro lado, porque, se bem que inconscientemente, ele nos mostra o caminho [que nos leva] deste labirinto dos sistemas ao conhecimento positivo real do mundo (Engels, 1982, pp. 384-385).

Ao lado da divulgação, portanto, tem-se o desenvolvimento das descobertas científicas de Marx. Isso somente seria possível, de um lado, com o abandono da pretensão de alcançar “verdade absoluta”, que se encontraria pressuposta, ao mesmo tempo em que desenvolvida, no sistema hegeliano. Ou seja, ao mesmo tempo em que Engels procura desenvolver de modo sistemático seu pensamento, bem como uma concepção de ciência que faça jus às descobertas de Marx, ele critica pesadamente o modo pelo qual o autor da Lógica traz a sistematicidade do pensamento. A hipertrofia do saber absoluto e da filosofia em Hegel teria como corolário a subordinação das ciências positivas ao pensamento especulativo; assim, o movimento dialético aparece hipostasiado e, com sua lógica, subordina a apreensão das determinações do real. Engels, portanto, procura reafirmar as ciências positivas para que o pensamento dialético não apareça como algo dotado de um movimento especulativo. Assim, notamos uma outra tendência bastante contraditória em nosso autor: ao mesmo

quase nada limitados pelo espírito burguês. Muito pelo contrário, o caráter aventureiro dessa época neles se refletiu em certa dose. Não existia, então, quase nenhum homem de certa importância que não tivesse feito extensas viagens; que não falasse quatro ou cinco idiomas; que não se projetasse em várias atividades. Leonardo da Vinci era não só um grande pintor, mas também um grande matemático, mecânico e engenheiro, a quem os mais variados ramos da física devem importantes realizações. Albert Dürer era pintor, gravador, escultor, arquiteto e, além disso, inventou um sistema de fortificações que continha várias das ideias, muito mais tarde assimiladas por Montalembert, das modernas fortalezas alemãs. [...] Os heróis dessa época não se achavam ainda escravizados à divisão do trabalho, cuja ação limitativa, tendente à unilateralidade, se verifica frequentemente entre seus sucessores. Mas o que constituía sua principal característica era que quase todos participavam ativamente das lutas práticas de seu tempo, tomavam partido e lutavam, este por meio da palavra e da pena, aquele com a espada, muitos com ambas. Daí essa plenitude e força de caráter que fazia deles homens completos. Os sábios de gabinete são a exceção: ou eram pessoas de segunda ou terceira classe, ou prudentes filisteus que temiam queimar os dedos" (Engels, 1979b, pp. 15-16). 
tempo em que ele critica o sistema hegeliano, com base nas descobertas científicas, e louvando o ímpeto da empreitada de seu antagonista, ele procura os sistemas que poderiam levar ao conhecimento positivo do real. De um lado, pois, tem-se a crítica a Hegel, doutro, a reafirmação das ciências positivas e a defesa de uma espécie de compêndio materialista em que elas não deixam de ter um papel importante a realizar. Assim, se Engels não é acrítico quanto às limitações das ciências de seu tempo, ao mesmo tempo, ele as reafirma. Isto ocorre tanto diante de Hegel quanto frente aos epígonos deste, bem como do pensamento burguês. Contra a especulação hegeliana e contra as robinsonadas requentadas dos epígonos, Friedrich Engels defende não só as descobertas de Marx, mas também uma concepção de ciência.

Ele defende as ciências positivas, mas não o positivismo. Louva um autor evolucionista como Morgan e, no campo das ciências naturais, Darwin; porém, não os vê como autores que não sejam problemáticos. Se parte considerável da tradição marxista do século XX (formadas na vigência da II e da III Internacional) foram acríticos quanto a grande parte da ciência de suas épocas, isto não se dá plenamente com Engels.

Sua exposição mais sistemática, por vezes, pode confundir o leitor. E, assim, não há como deixar de notar que há aberturas no texto do próprio Engels principalmente devidas a seu modo de exposição e ao fato de estar se colocando de modo polêmico a partir da obra de autores com os quais não concorda - para leituras apressadas.

O contexto em que nosso autor se coloca, porém, não é somente aquele das ciências positivas de sua época, nem aquele dos Dühring. Ele está debatendo com autores de enorme envergadura, como o autor da Enciclopédia das ciências filosóficas.

Engels, deste modo, critica a forma do sistema hegeliano. Mas reafirma a pretensão de um sistema de conhecimentos. A categoria "sistema" aparece no plural e sem a subordinação ao pensamento especulativo, tratando-se da apreensão do movimento do real, e não da busca da expressão da ideia na realidade efetiva. No que, neste ponto, tem-se um aspecto essencial para o pensamento engelsiano: a dialética hegeliana, neste sentido, teria levado inconscientemente para além dela mesma, principalmente devido ao seu método, correlacionado com o movimento, com o devir e contrário ao dogmatismo.

Ela representaria o cume da filosofia que se pensa como base do conhecimento positivo e, assim, traria de modo sistemático um compêndio ordenado deste conhecimento, mas de modo invertido: de acordo com Engels, se é verdade que este conhecimento mesmo é que fundamenta a possibilidade da apreensão da totalidade da realidade efetiva, em Hegel, a realidade efetiva mesma aparece como a extrusão da ideia. Um dos grandes méritos do autor da Enciclopédia das ciências filosóficas teria sido explicitar o caminho que vai dos sistemas parciais do conhecimento à apreensão 
da efetividade. $\mathrm{E}$, deste modo, pode-se dizer que a pretensão engelsiana liga-se tanto à divulgação das bases do pensamento científico - relacionada à teoria do valor, bem como à concepção materialista da história - quanto ao desenvolvimento de um compêndio baseado nas ciências positivas que nos pudesse levar ao conhecimento positivo do mundo.

$E$, com isto, pode-se dizer que o projeto de Friedrich Engels é bastante ousado: remete a uma compreensão científica da natureza e da história, ao mesmo tempo em que procura se esquivar dos erros que teriam sido cometidos por Hegel. Seu projeto aceita certos aspectos das ciências positivas; porém, critica as limitações de seus procedimentos e de seus métodos, derivados de uma época em que as limitações da divisão do trabalho se colocam também na atividade intelectual e nos próprios intelectuais. ${ }^{4}$

Em meio a um embate com Hegel, as ciências positivas tanto são objeto de crítica quanto um ponto de apoio para o desenvolvimento de uma concepção dialética. $\mathrm{E}$, com isto, é preciso que desenvolvamos um pouco mais a concepção de dialética de nosso autor.

\section{Dialética, sistema e método}

É central para nosso autor a oposição entre dialética e metafísica. O modo pelo qual pensa a apreensão da realidade procura explicitar o movimento do real, bem como seu caráter processual. Desta maneira, sua concepção de dialética traria consigo a gênese e o fenecimento das esferas e dos entes que compõem a realidade.

Segundo ele, tal caráter dinâmico do real já apareceria até mesmo para certas formas de materialismo que se desenvolvem ultrapassando o iluminismo, bem como, até certo ponto, para as ciências da natureza de sua época (cf. Engels, 2015, pp. 77-116). Ter-se-ia, de um lado, uma posição dogmática e incapaz de apreender as determinações da própria realidade: trata-se da metafísica. Doutro, haveria a dialética, a qual procuraria conjugar as ciências positivas com o caráter processual e objetivo da realidade objetiva.

O interessante da posição de Engels aparece ao passo que ele pensa nos sistemas das ciências positivas, que remetem a diferentes métodos para lidar com o real. Tem-se também a ênfase do nosso autor em formas de proceder diferenciadas para cada objeto. Sobre este aspecto, diz-se no Anti-Dühring sobre a dialética, a metafísica e as ciências:

\footnotetext{
4 Aqui não podemos tratar da questão, mas tal projeto não deixa de se aproximar daquele materialismo interdisciplinar defendido por Max Horkheimer no começo de sua carreira. Destaca-se, nestes textos, a importância da distinção entre metafísica e dialética, central para Engels (cf. Horkheimer, 1990).
} 
Todos esses processos e métodos de pensar não cabem na moldura do pensamento metafísico. Para a dialética, em contrapartida, que concebe as coisas e seus retratos conceituais essencialmente em seu nexo, em seu encadeamento, em seu movimento, em seu devir e fenecer, processos como os anteriormente mencionados são outras tantas conformações de seu modo de proceder (Engels, 2015, p. 51).

Diferentemente do que se daria em Hegel, não haveria uma unidade especulativa para as ciências; antes, a ciência é que subordinaria a compreensão da totalidade do real. Engels fala do fim da filosofia clássica alemã; porém, também diz que "o movimento operário alemão é o herdeiro da filosofia clássica alemã” (Engels, 1982, p. 421-422). Ou seja, o modo pelo qual nosso autor enxerga a filosofia clássica alemã, e principalmente Hegel, é aquele de alguém que se coloca em ruptura, mas também em continuidade com tal tradição (cf. Korsch, 2008). Trata-se de uma negação que afirma o essencial daquilo superado elevando-o a um patamar superior. Ou seja, a concepção hegeliana de Aufhebung (superação, supressão e suprassunção) parece ser adequada para se referir à maneira pela qual Engels se relaciona com a filosofia hegeliana.

Esta última estaria no ápice do desenvolvimento dialético burguês, sendo preciso teórica e praticamente superá-la. Isto se daria tanto porque haveria uma espécie de verdade absoluta plasmada no idealismo especulativo hegeliano, quanto porque a correlação entre filosofia e ciência, no autor da Enciclopédia das ciências filosóficas, traria consigo certo dogmatismo e, portanto, certo elemento metafísico. Neste sentido, seria preciso colocar a dialética sobre os próprios pés, remetendo-se a uma concepção materialista da história. Seria premente também uma crítica às próprias estruturas sociais do presente, estando isto, na verdade, ausente na dialética hegeliana. Ou seja, em Engels, há uma crítica ao sistema hegeliano também porque ele não consegue ser coerente com a própria dialética. $E$ isto ocorre na medida em que aquele que consegue negar a filosofia clássica alemã - o proletariado alemão também é aquele que a leva adiante.

$\mathrm{E}$, assim, se a metáfora sobre a inversão de Hegel, sobre a crítica de um sistema que se colocasse sobre a cabeça, talvez seja imprecisa ou insuficiente quanto a Marx (cf. Lukács, 1959; Chasin, 2009; Sartori, 2014), no que diz respeito à crítica engelsiana ao sistema hegeliano, ela tem grande parcela de verdade. Engels, no entanto, não se enxerga somente como um herdeiro de Hegel; ele, em meio à oposição entre pensamento metafísico e dialético, coloca-se como herdeiro de uma tradição que iria de Aristóteles a Hegel, passando por Spinoza e pelos iluministas. 0 chão da realidade, deste modo, colocaria o socialismo como ciência, ao passo que a dialética teria um grande valor: 
Para fazer do socialismo uma ciência, ele precisou primeiro ser posto sobre o chão da realidade. Nesse meio-tempo, surgiu, ao lado e depois da filosofia francesa do século XVIII, a mais nova filosofia alemã, encontrada em Hegel e sua finalização. Seu maior mérito foi a retomada da dialética como forma suprema de pensamento. Os antigos gregos haviam sido dialéticos naturais, natos, e a mente mais universal dentre eles, Aristóteles, já tinha examinado as formas essenciais do pensamento dialético. A filosofia mais recente, em contrapartida, embora também tivesse representantes brilhantes na dialética (por exemplo, Descartes e Spinoza), havia se atolado mais e mais, graças à influência inglesa, no modo metafísico de pensar, que reinava quase absoluto também sobre os franceses do século XVIII, ao menos em seus trabalhos especificamente filosóficos. Fora da filosofia propriamente dita, eles também eram capazes de oferecer obras-primas da dialética; basta lembrar de $O$ sobrinho de Rameu, de Diderot, e do Discurso sobre a origem e os fundamentos da desigualdade dentre os homens, de Rousseau (Engels, 2015, pp. 48-49).

A concepção de ciência de Engels procura se ver como herdeira de toda uma tradição, que traria consigo as formas essenciais do pensamento dialético. A inversão da dialética hegeliana se dá sob alguns aspectos, como aquele relacionado à correlação entre sistema e método, bem como à oposição entre ciência e filosofia. Porém, a concepção engelsiana de dialética é mais ampla que aquela normalmente adotada ao se estudar Marx.

Ela tem por central a oposição (que é uma contribuição muito mais engelsiana que marxiana, e que já estaria presente em Hegel) entre sistema e método, bem como entre metafísica e dialética. 0 modo de Engels dar continuidade, ao mesmo tempo em que realiza uma ruptura, àquilo que aparece no sistema hegeliano é dúplice: ele remete a pensadores anteriores a Hegel, bem como a autores materialistas que compõem, mesmo que de modo muito meandrado (basta pensar em Rousseau), o iluminismo. Mas também se utiliza do autor da Enciclopédia das ciências filosóficas para trazer a própria oposição que é central à categorização engelsiana da dialética, aquela entre metafisica e dialética:

O velho método de investigação e de pensamento que Hegel chamava "metafísico", que se ocupava preferentemente com a investigação das coisas como permanências [Bestände] fixas dadas e cujos restos ainda assombram fortemente a nossa cabeça, teve, no seu tempo, uma grande justificação histórica. As coisas tinham de ser investigadas primeiro, antes de que os processos pudessem ser investigados. Tinha que se saber primeiro o que uma qualquer coisa era, antes de se poder aperceber das transformações que se processavam nela. E assim aconteceu na ciência da Natureza. A velha Metafísica, que tomava as coisas como prontas, surgiu a partir de uma ciência da Natureza que investigava as coisas mortas e vivas como prontas (Engels, 1982, p. 408).

Engels empresta de Hegel a concepção de metafísica, portanto. E, com isto, sua crítica ao dogmatismo da metafísica, de certo modo, já estava presente no autor da Fenomenologia do espírito. As ciências da natureza que tinham como modelo a 
matemática teriam oferecido o modelo para a apreensão do real e, assim, haveria certa oposição entre as coisas e os processos. As primeiras seriam vistas como prontas, sendo aquilo que caracteriza uma posição dialética a negação deste caráter reificado da realidade. Ou seja, também neste sentido, há continuidades marcantes por parte de Engels no que se relaciona com a tradição dialética que ele menciona. Tratar-se-ia de um modo de proceder diante da realidade, enxergando-a enquanto marcada pelos processos, pelo movimento e, no limite, pelo caráter transitório dos entes específicos. Assim, haveria certo método na dialética. E este método entraria em uma contradição profunda com o fechamento dos sistemas; Engels, assim, aponta em Hegel uma contradição entre sistema e método. Ele também vê o nascimento das ciências naturais como um grande avanço na possibilidade de entender a realidade efetiva; porém, tal qual ocorreria no modo metafísico de apreensão da realidade, haveria falhas que precisariam ser superadas. 0 mecanicismo da maioria dos materialismos dos iluministas seria inaceitável para o presente, por exemplo. Mesmo que justificada em sua época, ele precisaria ser superado:

O materialismo do século passado era predominantemente mecânico, porque, de todas as ciências da Natureza daquela altura, apenas a mecânica, e, a bem dizer, também só a dos corpos sólidos - celestes e terrestres -, em suma, a mecânica dos graves, tinha chegado a um certo acabamento. [...] A segunda limitação específica deste materialismo consistiu na sua incapacidade de apreender o mundo como um processo, como uma matéria compreendida numa continuada formação [Fortbildung] histórica. Isto correspondia ao estado da ciência da Natureza da altura e à maneira metafísica, isto é, antidialéctica, do filosofar, com aquele conexa (Engels, 1982, p. 393).

Haveria uma ligação entre o estado das ciências de uma época e o desenvolvimento de uma posição dialética. No Anti-Dühring, Engels disserta longamente sobre o assunto e, mesmo que tenha críticas às ciências de seu tempo, enxerga a concepção materialista da história como afinada com os desenvolvimentos mais interessantes das ciências naturais. Ao caráter mecânico das ciências de uma época, estaria ligada uma concepção incapaz de lidar com o movimento e os processos presentes na própria matéria. Ou seja, neste contexto, a metafísica teria terreno fértil, já que haveria certa incapacidade de apreender o mundo com um processo. A maneira metafísica de filosofar, deste modo, oscilaria entre uma tonalidade idealista e um materialismo mecanicista, ambos igualmente limitados. Hegel seria aquele a tentar superar tal oposição; porém, o autor teria uma espécie de amor ao sistema, que o impediria de ser consequente com o próprio modo dialético de se proceder. Ao contrário de Descartes, de Spinoza, de Rousseau, de Diderot, Hegel já teria à sua disposição um maior desenvolvimento das ciências da natureza. Isto faria com que ele, de certo modo, pudesse ir além do modo plasmado pelo qual se coloca seu sistema. Porém, não foi o que se deu. E isto se deveria tanto às especificidades 
do pensamento hegeliano quanto ao seu comprometimento com a efetividade da moderna sociedade civil-burguesa.

Há, portanto, uma limitação inerente ao pensamento hegeliano, assim como no pensamento dos filósofos do século XVIII. Isso se deve ao momento em que elaboram suas perspectivas e em que as oposições basilares da sociedade capitalista ainda não estariam claras o suficiente (cf. Engels, 2015, pp.289-319). Isto ocorreria, e de modo ainda mais claro, nos chamados socialistas utópicos (cf. Engels, 1962, pp. 41-84). Para o que diz respeito à concepção engelsiana de dialética, há de se ver como que o movimento especulativo da filosofia hegeliana alcançaria também a natureza, que seria uma espécie de extrusão da ideia. E, deste modo, a posição hegeliana sobre a natureza seria indissociável de seu apego ao fechamento do método e, portanto, traria tanto um tom idealista quanto metafísico:

Podemos tão pouco censurar por isso os filósofos do século XVIII quanto também a encontramos em Hegel. Para este, a Natureza, como mera "exteriorização" da $^{2}$ Ideia, não é capaz de nenhum desenvolvimento no tempo, mas apenas de um estirar da sua multiplicidade no espaço, de tal modo que estende todos os estádios de desenvolvimento nela compreendidos simultaneamente e um ao lado com outro, e está condenada à eterna repetição sempre do mesmo processo. E este contrassenso de um desenvolvimento no espaço, mas fora do tempo - a condição fundamental de todo o desenvolvimento -, imputa-o Hegel à Natureza, precisamente, no mesmo tempo em que a geologia, a embriologia, a fisiologia vegetal e animal e a química orgânica se formavam e em que, por toda a parte, na base destas novas ciências, emergiam pressentimentos geniais da ulterior teoria do desenvolvimento [Entwicklungstheorie] (por exemplo, Goethe e Lamarck). Mas o sistema exigia-o assim, e o método tinha, por amor ao sistema, de ser, assim, infiel a si próprio (Engels, 1982, p. 394).

Tanto nos filósofos do século XVIII quanto em Hegel haveria uma concepção equivocada sobre a natureza. Os primeiros trariam à tona uma posição mecanicista sobre este importante elemento da realidade; o segundo adotaria uma posição idealista sobre o assunto: a natureza seria uma espécie de extrusão, alienação (Entäusserung) da ideia. E, com isto, a autarquia relativa da natureza, tão central às ciências naturais, seria deixada de lado. Sob este aspecto, o autor da Enciclopédia das ciências filosóficas seria profundamente idealista, deixando, ao mesmo tempo, de apreender o movimento que existe na própria natureza no transcorrer do tempo e de reconhecer que as leis imanentes da natureza possuem certa independência quanto à consciência e quanto ao espírito.

0 desenvolvimento que ele percebia tão bem na história parecia estar ausente na natureza. E, com isto, as concepções de Goethe, no campo das ciências relacionadas mais diretamente à história, e de Lamarck, ligado às ciências da natureza, seriam superiores à hegeliana sob este aspecto. O apego do autor da Enciclopédia das ciências filosóficas ao sistema faria com que, em oposição ao seu próprio método,

5 Termo traduzido por nós acima como extrusão e referente ao alemão "Entäusserung”. 
isto se desse.

Hegel, no limite, seria infiel a si próprio. E, deste modo, haveria no autor uma oposição marcante entre sistema e método. Esta última teria por trás de si tanto uma concepção equivocada de natureza quanto uma relação com o presente que via este último como aquele tempo da realização da razão na história. A oposição mencionada, portanto, não é simplesmente um descuido hegeliano. Faz parte da própria constituição de sua filosofia. Aliás, sobre a filosofia, há um aspecto bastante importante que é criticado por Engels: no desenvolvimento hegeliano deste campo, esta última chama para si todos os aspectos da realidade e, de modo especulativo, subordina as ciências positivas.

O sistema hegeliano, portanto, tem ligação íntima com este papel atribuído pelo autor da Lógica à filosofia. As concatenações universais das coisas parecem poder ser estabelecidas pelo movimento das categorias explicitadas na ideia, sendo que, em verdade, estas concatenações não subordinam o movimento das coisas, mas explicitam aquilo que está presente na própria realidade efetiva; espelham a realidade, portanto. ${ }^{6}$

Para Engels, pois, a dialética é um modo de proceder diante do espelhamento da realidade efetiva. Não se trata, portanto, de uma filosofia que se pretenda marcada por uma verdade absoluta; não se tem a subordinação das ciências positivas à filosofia. Se isto acontece, como em Hegel, há uma oposição entre o método dialético e o sistema. O sistema hegeliano, portanto, tem ligações íntimas tanto com o papel que a filosofia ocupa em seu pensamento quanto em suas concepções sobre a natureza e a história.

Engels traz a questão da seguinte maneira, que não deixa de trazer alguns problemas de difícil lida para o tema que aqui estamos abordando:

Desde o momento em que cada ciência tem que prestar contas da posição que ocupa no quadro universal das coisas e do conhecimento dessas coisas, já não há margem para uma ciência especialmente consagrada ao estudo das concatenações universais. Da filosofia anterior, com existência própria, só permanece de pé a teoria do pensar e de suas leis: a lógica formal e a dialética. 0 demais se dissolve na ciência positiva da natureza e da história (Engels, 1962, pp. 60-61).

O autor reafirma sua crítica ao desenvolvimento de uma filosofia especulativa e idealista. Faz isso tanto ao contrapor o sistema ao método quanto ao trazer à tona a necessidade de valorização das ciências positivas. Ainda acrescenta que há diferenças específicas entre o campo da natureza e da história ao mesmo tempo em

6 A crítica de Engels ao idealismo hegeliano fica clara aqui: "a isso se associava um terceiro aspecto. Hegel era um idealista, isto é, as ideias em sua mente não equivaliam, para ele, a retratos mais ou mesmo abstratos das coisas e dos processos reais, mas, em vez disso, as coisas e seu desenvolvimento eram apenas retratos mais ou menos abstratos da 'ideia' que já existia em algum lugar antes do mundo. Desse modo, tudo foi posto de cabeça para baixo e o nexo real do mundo foi completamente invertido" (Engels, 2015, p. 53). 
que se opõe à segmentação do conhecimento. Ele vem a apontar a existência da ciência positiva da natureza, de um lado, e da história, doutro. Ou seja, não traz a valorização das ciências positivas como algo pensado tradicionalmente, segmentado, cego diante da estrutura unitária da realidade. Engels, portanto, procura estipular que há um tratamento dialético a ser dado ao mundo; com este tratamento, os processos, o movimento e o fenecimento são analisados tanto no que diz respeito à natureza quanto à história.

A dialética, portanto, aparece não tanto como um método a priori, mas como um modo de se proceder diante da realidade a fim de se apreender o ser-propriamenteassim dela. Porém, o modo pelo qual nosso autor se refere à filosofia pode causar confusão: mesmo que ela não fosse mais hipostasiada, restaria dela uma teoria sobre o pensar e sobre as leis do pensamento. Engels, portanto, pontua a impossibilidade de se dar uma autonomia às leis da dialética, às concatenações universais, mas, ao mesmo tempo expressa-se de modo a valorizar a lógica formal e a dialética como algo com certa autonomia. $E$ isto, no limite, parece trazer certa tensão ${ }^{7}$ ao próprio pensamento engelsiano: sua exposição, por vezes, aproxima-se daquelas dos autores com os quais debate, sendo que o conteúdo que ele traz e que pesquisa talvez não caiba com toda a precisão nas categorias que são usadas. Com isto, há uma tensão entre a exposição e a pesquisa engelsiana; ela faz com que, por vezes, venhamos a ser tentados a ler a teoria do autor de modo sistemático, tal qual teria ocorrido em Hegel. Ele, explicitamente, é contrário à tal leitura. Porém, há de se admitir que seu próprio texto dá certo espaço para ela. Por vezes, a falha que Engels apontou em Hegel, em menor grau, parece estar presente em seu pensamento. Parece haver certa contradição entre a tematização engelsiana da dialética e o modo pelo qual a dialética parece se explicitar, juntamente com a lógica formal, e como uma teoria sobre o pensar e suas leis. 0 modo pelo qual Engels lida com a natureza, com a ciência e com a dialética, ao mesmo tempo, o aproxima e o afasta de Hegel, sendo preciso sempre explicitar como isso se dá em cada caso.

\section{Apontamentos finais: Sistema, método, política e Hegel na peruca do filisteu}

Engels desenvolve-se em oposição a Hegel, mas também procurando dar continuidade à tradição cujo ápice, na época, está no pensamento deste autor, a tradição dialética. Com isto, ao mesmo tempo, aponta contradições no pensamento hegeliano e traz tensões bastante notáveis para seu próprio pensamento, que não deixou de expressar certa relação conflituosa no que toca o modo de pesquisa e de exposição.

7 Alguns talvez até mesmo poderiam dizer se tratar de uma tensão entre sistema e método. 
Diz-se, assim, que "o sistema de Hegel foi um aborto gigantesco, mas o último de seu gênero. De fato, continuava sofrendo de uma contradição interna incurável" (Engels, 1962, p. 60). O autor do Anti-Dühring admira muito Hegel - por exemplo, por o autor "abarcar um domínio incomparavelmente maior do que qualquer sistema anterior e de desenvolver nesse domínio uma riqueza de pensamento que ainda hoje causa espanto" (Engels, 1982, p. 383). Porém, o sistema hegeliano está plasmado no presente, havendo uma ligação ineliminável entre a posição política de Hegel e a contradição entre sistema e método, que marca sua filosofia de modo umbilical.

Nosso autor diz que "um sistema universal e definitivamente plasmado do conhecimento da natureza e da história é incompatível com as leis fundamentais do pensamento dialético" (Engels, 1962, p. 60) e, assim, está a criticar Hegel. Mas sabe que sua crítica precisa remeter às bases materiais da coisa, que trazem a um patamar superior a mencionada oposição entre sistema e método dialético. Diz Engels sobre Hegel que "as necessidades internas do sistema só chegam, portanto, para explicar a produção de uma conclusão política muito dócil, por intermédio de um método de pensar de par em par revolucionário" (Engels, 1982, p. 383). E, portanto, vemos que a crítica, bem como a inversão engelsiana do pensamento hegeliano, não flutuam no ar. Elas trazem consigo uma posição sobre o presente. Esta posição certamente não está colocada de modo abrupto: Engels procura uma crítica imanente, não só ao pensamento hegeliano, mas como à época em que se desenvolve tal pensamento. Diz-se, assim, que "Goethe, tal como Hegel, eram, cada um no seu domínio, um Zeus olímpico, mas ambos nunca se viram totalmente livres do filisteu alemão" (Engels, 1982, p. 383). Assim, se Hegel não conseguia ser fiel com a própria dialética que deu vida a seu pensamento, isto se dava por razões bastante concretas, sendo preciso andar, com Hegel, mas também contra Hegel.

$E$, por isto, não se tem em Engels só uma inversão quanto à relação entre ciência e filosofia, ou quanto ao idealismo; segundo nosso autor, a partir da "dissolução da escola" hegeliana saiu "ainda uma outra orientação, a única que realmente deu frutos, e esta orientação liga-se essencialmente ao nome de Marx" (Engels, 1982, p. 406). Pelo que vemos aqui, é possível dizer que Engels enxerga isto na medida em que a posição de Marx teórica e praticamente supera a hegeliana, estando ligada, no limite, à emergência do movimento dos trabalhadores, e não mais às condições de consolidação da sociedade civil-burguesa. Neste sentido, seria o movimento dos trabalhadores alemães, ao mesmo tempo, o herdeiro da filosofia clássica alemã e aquele que poderia suprimir as condições das quais esta depende. $\mathrm{E}$, se formos pensar com Engels, a análise dos textos da época, bem como da relação do autor do Anti-Dühring com a dialética também precisa ser pensada ao ter em conta os destinos deste próprio movimento político. A oposição entre sistema e método, entre metafísica e dialética, precisa ser analisada tanto ao se apreender a crítica 
engelsiana a Hegel quanto ao passo que se explicita a importância de uma posição concreta diante da realidade para que se compreenda as formas ideológicas mais diversas, como aquelas colocadas no campo da filosofia hegeliana, por exemplo.

\section{Referências}

Chasin, J. (2009). Marx: Estatuto Ontológico e Resolução Metodológica. São Paulo, SP: Boitempo.

Engels, F. (1962). Do socialismo utópico ao socialismo científico; Ludwig Feuerbach e o fim da filosofia clássica alemã. Tradução de José Severo de C. Pereira. São Paulo, SP: Fulgor.

Engels, F. (1979 a). Esboço de uma crítica à economia política. Tradução de Maria Filomena Vieras. Revista Temas de Ciências Humanas. São Paulo, SP: Livr. Ed. Ciências Humanas, 5.

Engels, F. (1979 b). Dialética da natureza. Rio de Janeiro, RJ: Paz e terra.

Engels, F. (1982). Ludwig Feuerbach e o fim da filosofia clássica alemã. Tradução de José Barata-Moura. In: Obras escolhidas. Moscovo, URSS.

Engels, F. (1988). A questão da habitação. Tradução de equipe Aldeia Global. São Paulo, SP: Aldeia Global.

Engels, F. (2015). Anti-Dühring. Tradução de Nélio Schneiderman. São Paulo, SP: Boitempo.

Horkheimer, M. (1990). Teoria crítica I. Tradução de Hilde Cohn. São Paulo, SP: Perspectiva.

Korsch, K. (2008). Marxismo e filosofia. Tradução de José Paulo Netto. Rio de Janeiro, RJ: UFRJ.

Lukács, G. (1959). El Asalto a la Razón. Tradução de Wenceslau Roces. México, México: Fundo de cultura econômica.

Lukács, G. (2010). Prolegômenos para uma Ontologia do Ser Social. Tradução de Lya Luft e Rodnei Nascimento. São Paulo, SP: Boitempo.

Marx, K. (1996). O capital, Livro I, Volume I. Tradução de Regis Barbosa e Flávio R. Kothe São Paulo, SP: Nova Cultural.

Musse, R. (1999). Sistema e Método no Último Engels. Discurso, 30, 87-100. DOI: https://doi.org/10.11606/issn.2318-8863.discurso.1999.38028

Musse, R. (2005). A dialética como discurso do método. Tempo Social. Revista de sociologia da USP, 1 (17), 367-389.

DOI: https://doi.org/10.1590/S0103-20702005000100016

Sartori, V. (2014). De Hegel a Marx: da inflexão ontológica à antítese direta. Kriterion [online], 55 (133), 691-713.

DOI: https://doi.org/10.1590/S0100-512X2014000200014

Sartori, V. (2015). Apontamentos sobre dialética e história em Friedrich Engels. Revista On Line de Filosofia e Ciências Humanas, 20, 122-133. 
Vitor Bartoletti Sartori

Sartori, V. (2020). A crítica marxista do Direito diante de Friedrich Engels: a tensão entre exposição e pesquisa em sua análise da esfera jurídica. Revista On Line de Filosofia e Ciências Humanas, 26 (2), 16-60.

Recebido em: 04.12.2020

Aceito em: 10.03.2021

Esta obra está licenciada com uma Licença Creative Commons Atribuição-NãoComercial-Compartilhalgual 4.0 Internacional.

https://creativecommons.org/licenses/by-nc-sa/4.0/

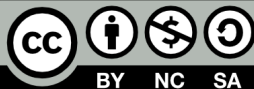

